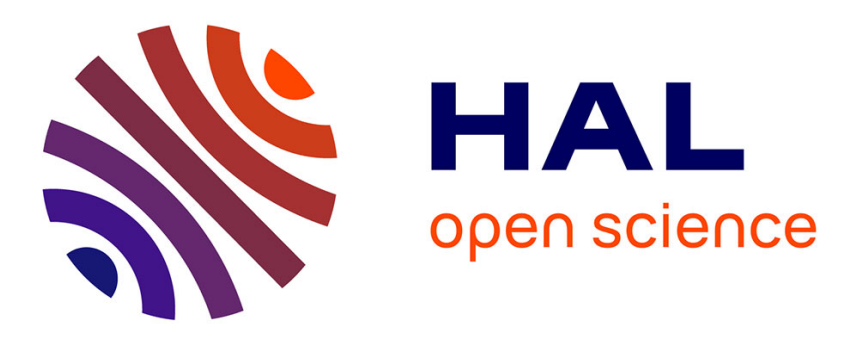

\title{
Textural and fluid inclusion constraints on the origin of the banded-iron-formation-hosted gold deposits at Maevatanana, central Madagascar
}

Prosper Andrianjakavah, Stefano Salvi, Didier Béziat, D. Guillaume, R. Rakotondrazafy, Bernard Moine

\section{To cite this version:}

Prosper Andrianjakavah, Stefano Salvi, Didier Béziat, D. Guillaume, R. Rakotondrazafy, et al.. Textural and fluid inclusion constraints on the origin of the banded-iron-formation-hosted gold deposits at Maevatanana, central Madagascar. Mineralium Deposita, 2007, 42 (4), pp.385-398. 10.1007/s00126006-0119-x . hal-00316068

\section{HAL Id: hal-00316068 https://hal.science/hal-00316068}

Submitted on 13 Nov 2020

HAL is a multi-disciplinary open access archive for the deposit and dissemination of scientific research documents, whether they are published or not. The documents may come from teaching and research institutions in France or abroad, or from public or private research centers.
L'archive ouverte pluridisciplinaire HAL, est destinée au dépôt et à la diffusion de documents scientifiques de niveau recherche, publiés ou non, émanant des établissements d'enseignement et de recherche français ou étrangers, des laboratoires publics ou privés. 


\section{Textural and fluid inclusion constraints on the origin of the banded-iron-formation-hosted gold deposits at Maevatanana, central Madagascar}

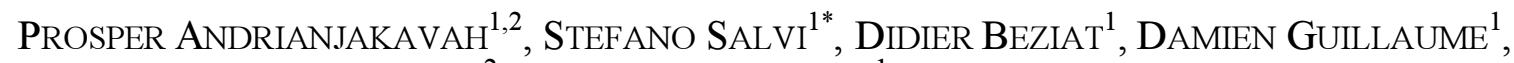
MICHEL RAKOTONDRAZAFY ${ }^{2}$ AND BERNARD MOINE ${ }^{1}$

${ }^{1}$ Laboratoire des Mécanismes et Transferts en Géologie - UMR 5563, CNRS/IRD/Université Toulouse 3, 14 avenue Edouard Belin, 31400 Toulouse, France

${ }^{2}$ Département des Sciences de la Terre, Faculté des Sciences, Université d'Antananarivo, Antananarivo, 101, Madagascar 


\section{Abstract}

The Maevatanana deposits consist of gold-bearing quartz-sulphide veins crosscutting banded iron formation (BIF) within a metamorphosed $2.5 \mathrm{Ga}$ greenstone belt. The host rocks are dominated by a sequence of migmatites, gneisses, amphibolites, magnetite-rich quartzites and soapstones, intruded by large granitoid batholiths (e.g. the $0.8 \mathrm{Ga}$ Beanana granodiorite). In the mineralised rocks, pyrite is the dominant sulphide, in addition to accessory chalcopyrite and galena. Outside the immediate ore zone, the BIF is dominated by quartz + magnetite \pm hematite, accompanied by cummingtonite, albite and biotite. Gold occurs as globular grains (usually $<500 \mu \mathrm{m}$ ) within quartz crystals close to the sulphides, and as invisible inclusions within pyrite and chalcopyrite (up to $2500 \mathrm{ppm}$ Au content).

Fluid inclusion textural and microthermometric studies indicate heterogeneous trapping of a low-salinity $(\sim 3.6$ $\mathrm{wt} \%$ eq. $\mathrm{NaCl}$ ) aqueous fluid coexisting with a carbonic fluid. Evidence for fluid-phase immiscibility during ore formation includes variable $\mathrm{L} / \mathrm{V}$ ratios in the inclusions and the fact that inclusions containing different phase proportions occur in the same area, growth zone, or plane. Laser Raman spectroscopy confirms that the vapour phase in these inclusions is dominated by $\mathrm{CO}_{2}$, but shows that it may contain small amounts of $\mathrm{CH}_{4}(<1 \mathrm{~mol} \%)$, $\mathrm{H}_{2} \mathrm{~S}(<0.05 \mathrm{~mol} \%)$ and traces of $\mathrm{N}_{2}$. Fluid inclusion trapping conditions ranged from 220 to $380^{\circ} \mathrm{C}$ and averaged $250^{\circ} \mathrm{C}$. Pressure was on the order of $1 \mathrm{kbar}$.

The abundant $\mathrm{CO}_{2}$ and low salinity of the inclusions suggest a metamorphic origin for the fluid. Likewise, the presence of $\mathrm{H}_{2} \mathrm{~S}$ in the fluid and pyritisation of the wall-rock indicate that gold was likely transported by sulphide complexing. Fluid immiscibility was probably triggered by the pressure released by fracturing of the quartzites during fault movements, due to competence differences with the softer greenstones. Fracturing greatly enhanced fluid circulation through the BIF, allowing reaction of the sulphide-bearing fluids with the iron oxides. This caused pyrite deposition and concomitant Au precipitation, enhanced by fluid phase separation as $\mathrm{H}_{2} \mathrm{~S}$ partitioned preferentially into the carbonic phase.

Keywords: Archaean mesothermal gold, aqueous-carbonic fluids, BIF, fluid immiscibility, Maevatanana, Madagascar 


\section{Introduction}

Very little is known about the gold potential of Madagascar, but the country's estimated gold production is approximately 3-4 tonnes/yr and could easily be doubled (Mining Annual Review 1995). This is a large amount considering that all of it presently comes from artisanal mining of mainly alluvial deposits. An estimate of Madagascar's total gold production since late last century is a respectable 70 tonnes. To this day, there is no organised or industrial gold exploitation. From what is known, most of the primary gold deposits of Madagascar belong to the mesothermal lode-gold class of deposits as defined by Hodgson (1993) (Rambeloson 1999; Nawaratne and Dissanayake 2001).

The Maevatanana gold district consists mainly of primary deposits in which mineralisation occurs as quartz-sulphide-gold veins. Gold is also found in alluvial sediments throughout the region, where it is exploited by locals. The Au-bearing veins crosscut ferruginous quartzite which is interpreted by Randriamanantenasoa (1992) as banded iron formation (BIF). Banded iron formations contain a major portion of the world's iron ores and, especially in Archaean terranes, host gold deposits (e.g. Gilligang and Foster 1987; Groves 1983; Pretorius et al. 1988; Hodgson 1993; Hagemann and Cassidy 2000). Gold mineralisation in these settings is debated as of an epigenetic (e.g. Phillips et al. 1984, Browning et al. 1987), versus a syngenetic origin (e.g. Fripp 1976). At Maevatanana, the mineralisation is clearly epigenetic because: 1) it occurs in a zone of deformed rock associated with a large regional shear-zone structure; 2) it is restricted to zones of intense fracturing with discordant quartz-sulphide veins; 3) textural evidence indicates replacement of primary magnetite by pyrite.

In this paper we present petrographic, microthermometric and Raman spectrographic data on fluid inclusions in vein quartz associated with the gold mineralisation. Characteristics of the fluids provide constraints on P-T conditions and mechanisms for gold precipitation. Based on these data we suggest a genetic model for the formation of the gold mineralisation at Maevatanana.

\section{Geological setting}

Madagascar forms a part of the Mozambique belt, resulting of continental collision between east and west Gondwana. Structures related to this event, such as vertical lithospheric-scale shear zones, are consistent with an east-west horizontal shortening (Martelat et al. 2000). Precambrian rocks form about two-thirds of Madagascar.

Present-day hypotheses on the Precambrian basement of Madagascar recognise seven tectonic units (cf. Collins and Windley 2002; Collins et al. 2003) (Fig. 1). The Archaean Antongil block to the east is regarded to be equivalent to the Dharwar craton in southern India, while the Antananarivo block in the centre has an African affinity. Both units are separated by the Betsimisaraka suture, which marks the collision of India with Africa during the assembly of Gondwana at about 550-500 Ma (Collins and Windley 2002). The Tsaratanana sheet is a system of greenstone belts overthrusted on the Antananarivo block. The remaining units to the west, south and far north are considered to be Proterozoic in age, thrusted over the Archaean units. Our study area is located in the central part of Madagascar within the Tsaratanana sheet area, in the Maevatanana belt (Fig. 2).

\section{Figure 1 Figure 2}

The Maevatanana belt is the westernmost tongue of the four north-south trending greenstone belts of the Tsaratanana area. The lithologies (e.g. Collins et al. 2003) consist of an 
infracrustal sequence of migmatite and a supracrustal sequence of gneiss, amphibolite (dated at $2502 \pm 2 \mathrm{Ma}, \mathrm{U}-\mathrm{Pb}$ on zircon, Tucker et al. 1999), magnetite-rich quartzites and metabasic to ultrabasic rocks (soapstones), intruded by large granitoid batholiths (e.g. the Beanana granodiorite dated at $779 \pm 2 \mathrm{Ma}, \mathrm{U}-\mathrm{Pb}$ on zircon, Tucker et al. 1999). These sequences were folded and metamorphosed under upper-greenschist to amphibolite facies conditions, probably during a widespread igneous event during the middle $(\sim 800-770 \mathrm{Ma})$ or possibly late Neoproterozoic ( 580-520 Ma) Pan-African event, which has been recognised in all of the Precambrian of Madagascar.

Gold-bearing quartz veins are found within a large high-strain zone interpreted as a regional brittle-ductile shear-zone that occurred late in the structural evolution of the belt.

\section{The Maevatanana gold district}

The Maevatanana goldfield was discovered in the late $19^{\text {th }}$ century, and a dozen small mines were operational by 1891. Exploitation was initially carried out by open-pit and underground mining; however, by the early 1900s alluvium was providing the largest part of the gold production, which reached half a tonne in 1909. Gold production then decreased rapidly, particularly after the start of the First World War. Since 1929, all gold extracted in the region is mined exclusively by gold panning (Besairie 1966). Recent estimates indicate an average gold grade of about $0.1 \mathrm{~g} /$ tonne (Nawaratne and Dissanayake 2001).

The most productive district has been defined by the polygon between the Ikopa, the Menavava and the Betsiboka Rivers, covering an area of about $7,500 \mathrm{~km}^{2}$, where at least 44 gold occurrences have been recorded (Besairie 1966). In this area, gold is exploited mainly in "black sands" alluviums but also by crushing the exposed quartz veins at their contact with laterite.

\section{Petrographic description of the lithologies}

Polished sections were prepared from about fifty selected samples collected nearby the Ikopa River within and around the ore bodies, including both host rocks and auriferous and/or nonauriferous quartz veins. All sections were studied under transmitted and reflected light in order to determine the mineral associations and parageneses.

Electron microprobe analyses on gold, sulphides, silicates and oxides were performed with a Camebax SX 50 Microbeam instrument (CAMECA) at the University Paul Sabatier in Toulouse, using an accelerating voltage of $15 \mathrm{kV}$, a beam current of $20 \mathrm{nA}$ and a $3 \mu \mathrm{m}$ beam diameter for all elements. Measuring time was $10 \mathrm{~s}$ for major and minor elements. Natural and synthetic minerals and pure metals were used as standards.

Gneisses represent the dominant lithological facies in the Maevatanana district, and can be subdivided into two main types: 1) amphibolite-biotite gneiss, consisting of $40 \%$ light coloured layers (quartz, microcline, orthoclase, plagioclase $\left(\mathrm{An}_{28}\right)$, apatite) and $60 \%$ darker layers (amphibole, biotite, iron and titanium oxides, plus titanite and zircon) and 2) muscovite-biotite gneiss, which consist of $65 \%$ of light coloured layers interbedded with layers consisting almost entirely of biotite.

Granitoid rocks are widespread throughout the area and occur as small layers or lenses within the gneisses. Their texture is granoblastic and they are composed of quartz, alkali feldspars, plagioclase and micas. Pegmatitic quartz-rich lenses, locally containing alkali-feldspar and biotite (plus accessory titanite, tourmaline and zircon), are common within the granites. Micro shear zones are widespread throughout these granites and affect the pegmatitic lenses as well. Mafic and ultramafic rocks at Maevatanana are represented by multi-metre thick regular layers, which are squeezed into the gneissic formations. They comprise two distinct facies: one showing a massive aspect and having a dark green colour (amphibolite sensu strictu) and 
a silkier, lightly coloured rock (soapstone). Mineral assemblages in these rocks indicate that peak metamorphism reached amphibolite-facies conditions. The amphibolite contains relicts of the amphibolite-facies assemblage, Mg-hornblende-albite-magnetite-mica-quartz-titanite. This assemblage is overprinted by the assemblage chlorite-epidote-calcite-hematite. In the soapstones, metamorphic hornblende is replaced by an assemblage of tremolite-albite-quartz, which is itself overprinted by anthophyllite, talc, chlorite or serpentine. These mineral assemblages suggest that greenschist-facies conditions prevailed, which is consisitent with the breakdown of Mg-hornblende to epidote and chlorite, and the presence of albite, which is probably a replacement of former plagioclase (oligoclase).

Magnetite-rich quarzites are found intercalated within the gneissic formations and amphibolites. These units commonly extend on kilometre-long layers, varying in thickness from a few centimetres to several metres wide. They consist of a succession of light coloured beds made up primarily of quartz and dispersed magnetite, intercalated with dark beds consisting mainly of magnetite and iron silicates (Fig. 3). This layered aspect led to their classification as banded iron formation (BIF) (Randriamanantenasoa 1992).

In the light layers quartz grains are anhedral, white coloured and range from 0.1 to $0.8 \mathrm{~mm}$ in size. Locally, fibrous or acicular amphibole (actinolite-type) can be observed within the quartz layers. Magnetite in these layers ranges in diameter from $\sim 20 \mu \mathrm{m}$ to $0.2 \mathrm{~mm}$ and occurs either as dispersed anhedral crystals or intergranular to the quartz grains.

The dark layers consist mainly of magnetite and amphibole. The magnetite content ranges from 10 to $40 \%$ of the whole rock; magnetite occurs as euhedral inclusions within quartz and is commonly pseudomorphed to hematite. Amphibole in the magnetite zone displays a subhedral texture and belongs to the cummingtonite-grunerite serie. Quartz veins can be commonly observed in these BIFs, and they can cross-cut or be concordant to the bedding.

\section{Figure 3}

\section{Gold mineralisation and alteration}

In the Maevatanana district, gold is hosted in quartz veins which occur mainly in the magnetite-rich quartzites (BIF) but which can be also found in the country rock, i.e. gneiss and mafic-ultramafic layers, adjacent to contacts with the BIF. Gold bearing quartz veins generally crosscut the BIF bedding, whereas veins that parallel the bedding are barren. The opposite is true for veins that occur in the country rock; here, mineralised veins are mostly concordant to the schistosity whereas discordant veins are barren. The mineralised veins are by and large oriented north-south and $\operatorname{dip} 70^{\circ} \mathrm{E}$.

\section{Table 1}

The auriferous veins are made up of fine-grained milky to smoky quartz which displays granoblastic textures (Fig. 3). Moderate to strong undulose extinction is also evident together with deformation lamellae. Quartz grains form polygonal aggregates of variable size which show no lattice-preferred orientation. These gold-bearing quartz veins also contain a distinct suite of sulphides, and less commonly, chlorite. Pyrite is the dominant sulphide in addition to chalcopyrite and galena (Table 1$)$. It occurs mainly as a replacement of magnetite ( \pm hematite) in the wall rock immediately adjacent to the quartz veins. It displays sutured or irregular surfaces in contact with magnetite bands, but subhedral to euhedral shape in contact with quartz layers. Chalcopyrite occurs as $1-\mathrm{cm}$ wide, isolated subhedral to anhedral grains (Fig. 3) or intergrown with pyrite. Galena is common in the quartz veins, where it forms $<4 \mathrm{~mm}$ anhedral grains that are commonly in contact with grey quartz and native gold (Fig. 4). The assemblage pyrite-chalcopyrite \pm galena after magnetite ( \pm hematite) is common along vein 
margins, at contacts with the wall rock, and appears to be contemporaneous to gold mineralisation (Fig. 3).

\section{Figure 4}

At a hand sample scale, gold is found within the sulphide-rich zones and occurs as free gold intergrown with pyrite \pm chalcopyrite and galena or as invisible gold within pyrite and chalcopyrite (about $2500 \mathrm{ppm}$ ). Pyrite and chalcopyrite compositions are homogeneous. Pyrite contains up to $5000 \mathrm{ppm}$ Co and $2400 \mathrm{ppm}$ As (Table 1).

\section{Table 2}

Gold in quartz veins (Fig. 4) is generally of microscopic size $(<500 \mu \mathrm{m})$, however, spectacular vein samples containing visible gold can be found. Electron microprobe analyses reveal that free gold is in the form of electrum, with an Ag content of about $7 \mathrm{wt} \%$ (Table 2), which is a common feature of BIF-hosted mesothermal lode-gold deposits $(<10 \mathrm{wt} \% \mathrm{Ag}$, e.g. Vielreicher et al. 1994).

\section{Fluid inclusion study}

Twenty-two doubly-polished thick sections were prepared from selected samples and examined by standard microscopy before undertaking further analyses. Microthermometric measurements were performed at the University Paul Sabatier in Toulouse, following the procedures outlined by Roedder (1984) and Shepherd et al. (1985), using a Linkam THMGS 600 heating-freezing stage mounted on a BX-51 Olympus microscope. The stage was calibrated against pure $\mathrm{H}_{2} \mathrm{O}$ synthetic inclusions $\left(0\right.$ and $\left.+374.1^{\circ} \mathrm{C}\right)$ supplied by SynFlinc and with pure $\mathrm{CO}_{2}$-bearing natural inclusions $\left(-56.6^{\circ} \mathrm{C}\right)$ from Campeirio (Ticino, Switzerland). Measurements below $0^{\circ} \mathrm{C}$ are accurate to $\pm 0.1^{\circ} \mathrm{C}$, whereas in heating runs temperatures are accurate to $\pm 1^{\circ} \mathrm{C}$. Cryogenic experiments were carried out before heating runs, to avoid the risk of decrepitating the inclusions. Salinity (expressed as $\mathrm{wt} \%$ eq. $\mathrm{NaCl}$ ), bulk composition, and density data were calculated by reducing raw thermometric data with the MacFlinCor software package of Brown and Hagemann (1995; cf. also Bakker and Brown 2003). Equations of state used were that of Bowers and Helgeson (1983) for the $\mathrm{H}_{2} \mathrm{O}-\mathrm{CO}_{2}-\mathrm{NaCl}$ system and that of Zhang and Frantz (1987) for the $\mathrm{H}_{2} \mathrm{O}-\mathrm{NaCl} \pm \mathrm{KCl}$ system.

\section{Petrographic characterization of fluid inclusions}

The Au-bearing veins are composed essentially of quartz ( $>90 \%$ vol.), and contain additional pyrite, chalcopyrite and galena. Abundant and diverse fluid inclusions are preserved in quartz. However, within milky and clear quartz it was difficult to clearly identify primary or secondary inclusions, because of the large number of inclusions and their unclear distributions. In contrast, smoky quartz crystals which surround or border sulphide-rich ore zones contain isolated individual inclusions and intergranular trails or clusters of randomly and three-dimensionally distributed inclusions. These fluid inclusions have negative crystal to ovoid shapes, range from 5 to $30 \mu \mathrm{m}$ in size and are constrained to individual quartz crystals (Fig. 5). Therefore, they are interpreted as primary or pseudosecondary in nature, i.e. they were trapped during vein-quartz crystallization, and thus were selected for further studies. Based on the number of phases observed at room temperature, filling degree, and phase variations during heating and freezing experiments, three fluid inclusion types could be identified:

\section{Figure 5}


- TYPE-I fluid inclusions are $\mathrm{CO}_{2}$-filled containing carbonic liquid (L) and vapour (V). Some type I inclusions contain only one phase (L) at room temperature but nucleate a vapour phase below ambient temperature. Type-I inclusions generally show regular forms (negative crystal shape), range in size from $\sim 5$ to $25 \mu \mathrm{m}$ and are isolated (primary), or less commonly occur on pseudosecondary trails.

- TYPE II aqueous-carbonic fluid inclusions predominate in our samples and contain three phases at room temperature $\left(\mathrm{H}_{2} \mathrm{O} \mathrm{L}, \mathrm{CO}_{2} \mathrm{~L}\right.$ and $\left.\mathrm{CO}_{2} \mathrm{~V}\right)$ (Fig. 5c). Like Type I inclusions, some Type-II inclusions only nucleate a $\mathrm{CO}_{2}$ vapour bubble upon cooling. Irregular, rounded, or negative crystal shapes are observed for Type-II inclusions. They can be randomly

distributed, clustered in the centres of grains, or occur in pseudosecondary trails. Their sizerange is similar to that of Type-I inclusions. The volumetric proportion of the $\mathrm{CO}_{2}$-rich phase varies from 30 to $70 \mathrm{vol} \%$, but is mostly between 50 and $70 \mathrm{vol} \%$.

-TYPE-III fluid inclusions contain either $\mathrm{H}_{2} \mathrm{O}$ liquid only (Type IIIa) or $\mathrm{H}_{2} \mathrm{O}$ liquid and vapour (Type IIIb) at room temperature. Type-IIIb inclusions are more abundant, and display a constant degree of filling ( $\mathrm{L} / \mathrm{V} \sim 0.90-0.95)$. They range in diameter from 5 to $35 \mu \mathrm{m}$ and vary in shape from irregular to round or ellipsoid.

Fluid inclusion assemblages comprising both Type-I and Type-II inclusions within the same cluster or trail are common, as are Type-II inclusions with variable proportions of $\mathrm{CO}_{2}$ and $\mathrm{H}_{2} \mathrm{O}$. However, the variation in $\mathrm{H}_{2} \mathrm{O} / \mathrm{CO}_{2}$ is less within individual groups and trails than among different grains. Type-I inclusions are only rarely associated with Type-III inclusions. Daughter minerals have not been found in any of the fluid inclusions studied, however, on rare occasions, we have observed Type-II and Type-III inclusions containing an apparently anisotropic trapped solid. The main components and timing of trapping of all inclusion types with respect to the host mineral are summarised in Table 3.

\section{Table 3}

\section{Microthermometric determinations}

\section{Type-I and Type-II fluid inclusions}

These inclusion types comprise more than $70 \%$ of the observed fluid inclusions. The melting temperature of $\mathrm{CO}_{2}$ ice $\left(\mathrm{T}_{\mathrm{m}} \mathrm{CO}_{2}\right)$ is close to the $\mathrm{CO}_{2}$ triple point $\left(-56.6^{\circ} \mathrm{C}\right)$ with a few measurements ranging down to $-57.1^{\circ} \mathrm{C}$ (Fig. 6a). Despite the notorious difficulty of observing clathrate (Roedder 1984), clathrate melting $\left(\mathrm{T}_{\mathrm{m}}\right.$ clath) data could be obtained from many Type-II inclusions using the double-freezing technique outlined by Collins (1979), which allowed clathrate melting to be observed in the absence of ice. In all aqueous-carbonic inclusions measured, clathrate melted at temperatures between 6.9 and $9.1{ }^{\circ} \mathrm{C}$ with a mode at $8.2 \pm 0.1^{\circ} \mathrm{C}$ (salinities between 1.8 and $5.9 \mathrm{wt} \%$ eq. NaCl; Fig. 7). The homogenisation of the carbonic phase $\left(\mathrm{T}_{\mathrm{h}} \mathrm{CO}_{2}\right)$ always occurred to liquid, and at temperatures from 7.3 to $30.9^{\circ} \mathrm{C}$ and from 25 to $31^{\circ} \mathrm{C}$ for Types I and II, respectively (Fig. 6b). These values correspond to bulk densities of 0.65 to $0.88 \mathrm{~g} / \mathrm{cm}^{3}$ and 0.73 to $0.94 \mathrm{~g} / \mathrm{cm}^{3}$ for Types I and II, respectively. Type-II inclusions display total homogenisation temperatures between 210 and $380^{\circ} \mathrm{C}$ with a peak at $280 \pm 30^{\circ} \mathrm{C}$ (Fig. 8). Indeed, the majority of Type-II fluid inclusions homogenise into a liquid phase between 250 and $310^{\circ} \mathrm{C}$, but some inclusions homogenise to the vapour phase at about $310 \pm 15^{\circ} \mathrm{C}(\mathrm{n}=11)$.

\section{Figure 6}




\section{Type-III fluid inclusions}

These inclusions display initial ice melting temperatures slightly lower than $-24^{\circ} \mathrm{C}$, which is close to the eutectic melting temperatures for the system $\mathrm{NaCl}-\mathrm{KCl}-\mathrm{H}_{2} \mathrm{O}\left(-22.9^{\circ} \mathrm{C}\right)$ and $\mathrm{NaCl}-$ $\mathrm{H}_{2} \mathrm{O}\left(-21.2^{\circ} \mathrm{C}\right)$. Final ice melting temperatures for aqueous inclusions range from -4.3 to $0.5^{\circ} \mathrm{C}$ with a mode at $-2.3 \pm 2{ }^{\circ} \mathrm{C}$ (salinities between 0.7 to $7.8 \mathrm{wt} \%$ eq. $\mathrm{NaCl}$ ) (Fig. 7 ). Total homogenisation temperatures were only recorded for Type-IIIb inclusions. These inclusions homogenised to the liquid phase between 130 and $270^{\circ} \mathrm{C}$, with a mode at $220 \pm 40^{\circ} \mathrm{C} \mathrm{(Fig.} \mathrm{8).}$

\section{Figure 7 \\ Figure 8}

\section{Laser Raman spectroscopy}

The microthermometric data were complemented by laser Raman spectroscopic analyses to obtain quantitative information of the solute composition of the fluids. Thirty-two carbonic and aqueous-carbonic inclusions (Types I and II), hosted in quartz intimately intergrown with gold and sulphides, were selected for analysis. Raman spectra were recorded on a Jobin Yvon-Horiba Raman Spectrometer (Labram type) at the University H. Poincaré in Nancy, France. The inclusions were illuminated with an exciting radiation of $514.5 \mathrm{~nm}$ from an ionised argon laser, focused through an 80X Olympus objective.

The analytical results indicate that the carbonic phase in both Type-I and Type-II inclusions mainly consists of pure $\mathrm{CO}_{2}$. However, the spectra revealed that Type-I inclusions contain a petrographically and microthermometrically undetectable film of water $(<5 \%)$. Therefore, these could be classified as Type-II inclusions with a high $\mathrm{CO}_{2}$ content. In addition, several of the type I and II inclusions trapped within quartz-sulphide ore zones, contain traces of $\mathrm{CH}_{4}$ $(<1 \mathrm{~mol} \%)$ and $\mathrm{H}_{2} \mathrm{~S}(<0.1 \mathrm{~mol} \%)$ (Fig. 9). In one case, we recorded the presence of $\mathrm{N}_{2}(<0.2$ mol\%) in a Type-I inclusion. These data explain the slight depression of the $\mathrm{CO}_{2}$ ice melting temperature observed during cooling runs. The trapped solids observed in some Type-II and Type-III inclusions have been identified by Raman analyses and consist mainly of biotite and more rarely nahcolite.

\section{Figure 9}

The computed bulk composition of all inclusion types is summarised in Table 4. Bulk properties of Type-I and Type-II inclusions (P-T-V-X) were computed using microthermometric data, assuming that the amount of $\mathrm{CH}_{4} \pm \mathrm{H}_{2} \mathrm{~S}$ (always $\leq 1 \mathrm{~mol} \%$ ) detected by Raman spectroscopy is negligible. The composition was estimated assuming the molar fraction of $\mathrm{CO}_{2}$ in the carbonic phase equal to $100 \%$ (Ramboz et al. 1985). For Type-I fluid inclusions we further assumed the presence of $5 \% \mathrm{H}_{2} \mathrm{O}$, undetected optically and during microthermometric runs, and absence of salts.

\section{Table 4}

\section{Discussion}

\section{Nature of the fluid and mechanisms of entrapment}

During petrographic examination of the fluid inclusion populations we separated a group of inclusions that appeared to contain only a carbonic phase (Type-I) from a second population that contained both aqueous and carbonic fluids, in varying proportions (Type-II). However, 
the results of laser Raman spectroscopy revealed the presence of "invisible" water in Type-I inclusions. These results suggest that Type-I and Type-II actually represent the same population of inclusions, which covers a wide range in carbonic gas content, i.e. from $\sim 15 \%$ to $>95 \%$. It follows that Type-I and Type-II inclusions trapped mixed aqueous-carbonic fluids, which is consistent with the fact that these two inclusion types were observed within nearly all selected samples and inclusion assemblages. Microthermometric measurements corroborate this hypothesis, as indicated by the similarity of the data for both inclusion types. Aqueous (Type-III) inclusions also occur in primary clusters or less commonly in pseudosecondary trails, within the same assemblages as Type-II inclusions. In addition, salinities of aqueous and aqueous-carbonic inclusions are within the same range (see above). Therefore, it is probable that Type-III inclusions represent the water-rich end member of the immiscible aqueous-carbonic fluid, just as Type-I inclusions trapped the $\mathrm{CO}_{2}$-rich end. Indeed, these results are in accordance with the basic criteria for evidence of fluid immiscibility in fluid inclusions (Ramboz et al 1982).

As mentioned above, microthermometric data display unimodal distributions (salinities, $\mathrm{T}_{\mathrm{m}} \mathrm{CO}_{2}, \mathrm{~T}_{\mathrm{h}} \mathrm{CO}_{2} \ldots$ ) for all inclusion types, except for total homogenisation temperatures (cf. Fig. 8) which show a scatter of about $60^{\circ} \mathrm{C}$ between Type-III $\left(\sim 220 \pm 40^{\circ} \mathrm{C}\right)$ and Type-II inclusions $\left(\sim 280 \pm 30^{\circ} \mathrm{C}\right)$. A similar inconsistency was also observed in fluid inclusions from the Wiluna lode-gold deposit in Australia (Hagemann and Lüders 2003). There, fluid inclusions in quartz were also interpreted to have been trapped during fluid immiscibility, and aqueous inclusions displayed a $\mathrm{T}_{\mathrm{h}}$ of about $70^{\circ} \mathrm{C}$ lower than that of aqueous-carbonic inclusions. Hagemann and Lüders (2003) attributed this discrepancy to loss of the $\mathrm{CO}_{2}$ (and $\mathrm{CH}_{4}$ ) dissolved in the water-rich portion of the immiscible fluid during pressure fluctuation. If pressure drops, these gases become less soluble and can separate from the water. A subsequent pressure rise would cause undersaturation of the remaining aqueous fluid with respect to $\mathrm{CO}_{2}$, and thus induce a lower homogenisation temperature of the inclusions.

\section{T-P-depth conditions during gold mineralisation}

As heterogeneous trapping of immiscible fluids was suggested by the data, the entrapment temperature is given by the homogenisation temperature of the aqueous-carbonic (Type-II) inclusions (eg. Diamond 1994). Because the pressure-temperature conditions of the fluid must lie along the isochores for the fluid inclusions, we can estimate the pressure during fluid entrapment. Figure 10 shows representative isochores covering the density range of Type-I (curves C-D) and Type-II (curves A-B) inclusions. Also traced in this figure are the $\mathrm{T}_{\mathrm{h}}$ tot average and $1 \sigma$ standard deviation values of Type-II inclusions, at $250 \pm 30^{\circ} \mathrm{C}$. The pressures obtained range approximately from 500 to 2100 bars, with an average of 1300 bars. Assuming that load conditions may have varied between hydrostatic and lithostatic pressures, and using pressure gradients of $\sim 1$ and $3.6 \mathrm{~km} / \mathrm{kbar}$, respectively, we can estimate a depth of formation between about 1.5 and $5 \mathrm{~km}$. Such shallow depths are typical of Archaean BIF-hosted mesothermal lode-gold deposits (e.g. Phillips and Powell 1992; Hagemann and Cassidy 2000).

\section{Figure 10}

\section{Implications of fluid immiscibility}

Fluid immiscibility of an originally homogeneous fluid has been documented for several Archaean lode-gold deposits, such as the Sigma mine in Quebec (Robert and Kelly 1987), the Bronzewing (Dugdale and Hagemann 2001), Cleo (Brown et al. 2003), and, as mentioned, the Wiluna lode-gold deposits (Hagemann and Volker 2003) in Western Australia. Fluid phase 
separation has been attributed to fluid pressure fluctuations triggered by fracture opening during cyclic fault movement (e.g. Sibson et al. 1988; Hagemann and Cassidy 2000; Brown et al. 2003). Given the evidence of structural control during formation of the quartz veins, it is possible that a similar process took place during gold mineralisation at Maevatanana.

Several studies have shown close spatial and temporal links between fluid immiscibility in the system $\mathrm{H}_{2} \mathrm{O}-\mathrm{CO}_{2}$ and the precipitation of gold, and provide evidence that fluid immiscibility can be an effective mechanism for gold deposition in lode-gold deposits. Seward (1989) interpreted fluid immiscibility to be the principal mechanism for gold precipitation in geothermal system. Mikucki and Groves (1990) suggested that gold deposition from a hydrothermal ore fluid via fluid immiscibility processes will depend on the initial fluid compositions and both the magnitude and relative rates at which $\mathrm{pH}, f \mathrm{O}_{2}$ and temperature vary during the event. On the other hand, Mikucki (1998) noted that heat loss and $\mathrm{fO}_{2}$ and $\mathrm{pH}$ increase during fluid immiscibility can act to inhibit gold deposition, and only the change in the sulphur activity favours gold precipitation. The boiling model is further complicated by experimental data of Williams-Jones et al. $(2002,2003)$ which suggest that metals such as Au are efficiently transported in the vapour phase. Within this scenario, separation of a vapour phase would probably enhance gold solubility and its transport within the vein system.

\section{Gold deposition model}

The Maevatanana deposits display many similarities to other Archaean lode-gold deposits such as Mt. Morgans and Cleo in Western Australia (Vielreicher et al. 1994; Brown et al. 2003, respectively), Hollinger-McIntyre in Ontario (Walsh et al. 1988), Fumani and Kalahari Goldridge in South Africa (Pretorius et al. 1988; Hammond and Moore 2006). A feature that is common to most of these deposits is the tectonic control of vein formation and the inferred metamorphic origin of the fluids. The high $\mathrm{CO}_{2}$ content and low salinity (see above) of the fluids, together with traces of $\mathrm{CH}_{4}$ and $\mathrm{N}_{2}$ found in the inclusions, suggest a similar origin for the Au-bearing fluids at Maevatanana, i.e. that they were probably produced by devolatilisation reactions during regional metamorphism (see also Kerrich and Fyfe 1981; Wyman and Kerrich 1988; Mikucki and Ridley 1993; Kerrich et al. 2000). The fact that the mineralised veins crosscut the BIF layering but are parallel to regional schistosity (see above) is consistent with a syntectonic origin of the fluid. The abundant basic and ultrabasic rocks within the Maevatanana belt most likely provided the source of Au to these hydrothermal fluids.

The BIFs rheological characteristics and high Fe content were probably the principal cause for Au deposition. Firstly, quartzite is more competent than the schistose wall rocks (soapstone, amphibolite, etc.). Shearing caused it to fracture thus allowing fluid migration. Secondly, the high Fe content provided a good chemical trap. The sulphide-oxide replacement textures observed in the ore zones, the occurrence of gold within pyrite, and the presence of $\mathrm{H}_{2} \mathrm{~S}$ gas detected in the fluid inclusions together with the low salinity of the fluid suggest gold transport by sulphide complexing (cf., Seward 1973; Zotov and Baranova 1989; Benning and Seward 1996; Gibert et al. 1998; Tagirov et al. 2005). It follows that wall-rock sulphidation could have been a potential mechanism for gold precipitation, through the destabilisation of gold thio-complexes. For the purpose of this discussion and in the absence of more precise control on the $\mathrm{pH}$ of the fluids, we assume $\mathrm{H}_{2} \mathrm{~S}^{0}$ to be the stable sulphur species in solution, which is reasonable in view of the fact that at about $250^{\circ} \mathrm{C}$ it predominates over a wide $\mathrm{pH}$ range, from acidic to moderately alkaline conditions (e.g. Barnes 1979). Furthermore, the presence of muscovite and $\mathrm{K}$-feldspar in addition to quartz observed in altered wall rocks would fix the fluid $\mathrm{pH}$ to weakly acidic conditions (QFM buffer).

\section{Figure 11}


Systematic replacement of magnetite by hematite is observed both in mineralised and in unmineralised BIF facies, suggesting that oxidising conditions only occurred after mineralisation, probably during supergene alteration. We therefore assume that the redox conditions prevailing in the quartzite were below those of the magnetite-hematite buffer (Fig. 11). In addition, the fact that pyrite occurs as replacement of magnetite indicates that the fluid was not in equilibrium with the host rock, but in the pyrite stability field, where Au solubility is much higher (Fig. 11). Replacement of magnetite by pyrite destabilised the Au complexes by reducing ligand availability, and drove the fluid to lower $a \mathrm{H}_{2} \mathrm{~S}$ and $f \mathrm{O}_{2}$ conditions, thereby drastically lowering gold solubility (arrow in Figure 11). We believe that this was likely the primary factor in causing Au mineralization, however, a further drive to Au precipitation would be the loss of sulphur that took place during fluid phase separation, due to preferential partitioning of $\mathrm{H}_{2} \mathrm{~S}$ into the exsolving $\mathrm{CO}_{2}$ phase.

\section{Conclusions}

The Maevatanana gold district is an example of an epigenetic lode-gold deposit that has undergone medium-grade metamorphism during a brittle tectonic event. The deposits consist of gold-bearing quartz-sulphide veins crosscutting banded iron formation hosted in a greenstone belt. Investigation of fluid inclusions hosted in Au-bearing vein quartz indicates heterogeneous trapping of a low-salinity aqueous fluid and a carbonic fluid containing traces of $\mathrm{H}_{2} \mathrm{~S}$. Fluid inclusion trapping conditions average at $250^{\circ} \mathrm{C}$ and $\sim 1 \mathrm{kbar}$.

The fluid was most likely of metamorphic origin, as indicated by the abundant $\mathrm{CO}_{2}$ and low salinity of the inclusions. Fluid immiscibility was probably triggered by the pressure released by fracturing of the quartzites during fault movements. The presence of $\mathrm{H}_{2} \mathrm{~S}$ in the fluid and the systematic pyritisation of the wall-rock indicate gold transport by thio-complexing. Fracturing enhanced fluid circulation through the BIF, where reaction of the sulphide-bearing fluids with the iron oxides caused pyrite deposition. Au precipitation was triggered by the two-fold decrease in ligand concentration of the fluid, as a consequence of lowering the $a \mathrm{H}_{2} \mathrm{~S}$ and $f \mathrm{O}_{2}$ as the fluid evolved towards rock-buffered conditions during fluid-rock interaction, and separation of a carbonic phase into which $\mathrm{H}_{2} \mathrm{~S}$ partitioned preferentially.

\section{Acknowledgments}

This study was supported by the Corus project nº 98518221 "Géologie du socle cristallin de Madagascar et de ses minéralisations". The authors thank the Malagasy government for financial support to PA during his MSc in Toulouse. We are grateful for the technical assistance on the Raman and microprobe analyses, which was provided by Thérèse Lhomme and Philippe de Parseval, respectively. This work benefited from valuable discussions with A.E. Williams-Jones and critical review by Bernd Lehmann.

\section{References}

Bakker RJ, Brown P (2003) Computer modelling in fluid inclusion research. In: Samson I, Anderson A, Marshall D (eds) Fluid Inclusions: Analysis and Interpretation. Short Course 32, Mineral Assoc Canada, pp 175-212

Barnes HL (1979) Solubilities of ore minerals. In: Geochemistry of Hydrothermal ore Deposits. $2^{\text {nd }}$ Edition (ed HL Barnes), Wiley, pp 404-460

Benning LG, Seward TM (1996) AuHS $^{0}$ : An important gold-transporting complex in high temperature hydrosulfide solutions. In: Kharaka and Chudaev (eds), Water-Rock Interaction, Balkema, pp 783-786

Bésairie H (1963) Description géologique du massif ancien de Madagascar. Volume I, Centre Nord et Centre Nord-Est, DBG $\mathrm{n}^{\circ} 177$, Service géologique de Madagascar, Antananarivo

Bésairie H (1966) Gîtes Minéraux de Madagascar. Ann. Geol. Madagascar 34, 822 pp

Bésairie H (1973) Carte géologique de Madagascar au 1:2 000000. Service géologique de Madagascar, Antananarivo 
Bowers TS, Helgeson HC (1983) Calculation of the thermodynamic and geological consequences of nonideal mixing in the system $\mathrm{H}_{2} \mathrm{O}-\mathrm{CO}_{2}-\mathrm{NaCl}$ on phase relations in geologic systems: Equation of state for $\mathrm{H}_{2} \mathrm{O}-\mathrm{CO}_{2}-\mathrm{NaCl}$ fluids at high pressures and temperatures. Geochim Cosmochim Acta 47: 1247-1275

Brown PE, Hagemann SG (1995) The program MacFlinCor and its application to geobarometry in Archaean lode-gold deposits. Geochim Cosmochim Acta 59: 3943-3952

Brown SM, Johnson-Craig A, Watling RJ, Premo WR (2003) Constraints on the composition of ore fluids and implications for mineralising events at the Cleo gold deposit, Eastern Goldfields Province, Western Australia. Aust J Earth Sci 50: 19-38 Browning P, Groves DI, Blockley JG, Rosman KJR (1987) Lead isotopic constraints on the age and source of gold mineralisation in the Archaean Yilgarn block, Western Australia. Econ Geol 82: 917-986

Collins AS, Windley BF (2002) The tectonic evolution of central and northern Madagascar and its place in the final assembly of gondwana. J Geol 110: 325-339

Collins AS, Fitzsimons IC, Hulscher B, Razakamanana T (2003) Structure of the eastern margin of the East African Orogen in central Madagascar. Precamb Res 123: 111-133

Collins LF (1979) Gas hydrates in $\mathrm{CO}_{2}$-bearing fluid inclusions and the use of freezing data for estimation of salinity. Econ Geol 74: 1435-1444

Diamond LW (1994) Introduction to phase relations of $\mathrm{CO}_{2}-\mathrm{H}_{2} \mathrm{O}$ fluid inclusions. In: De Vivo B, Frezzotti ML (eds.) Fluid Inclusions in Minerals: Method and Application. Virginia Polytechnic Institute \& State University, Blacksburg, pp 131-158 Dugdale AL, Hagemann SG (2001) The Bronzewing lode-gold deposit, Western Australia: P-T-X evidence for fluid immiscibility caused by cyclic decompression in gold-bearing quartz veins. Chem Geol 173: 59-90

Fripp REP (1976) Stratabound gold deposits in Archaean banded iron-formation, Rhodesia. Econ Geol 71: 58-75

Gibert F, Pascal ML, Pichavant M (1998) Gold solubility and speciation in hydrothermal solutions; experimental study of stability of hydrosulphide complex of gold $\left(\mathrm{AuHS}^{0}\right)$ at 350 to $450^{\circ} \mathrm{C}$ and 500 bars. Geochim Cosmochim Acta 62: 2931-2947 Gilligang JM, Foster RP (1987) Gold mineralisation in iron-formation: the importance of contrasting modes of deformation at the Lennox Mine, Zimbabwe. In: African Mining, Inst. of Mining and Metallurgy, London, pp 127-138 Groves DI (1993) The crustal continuum model for late-Archaean lode-gold deposits of the Yilgarn Block, Western Australia. Miner Deposita 28: 366-374

Hammond NQ and Moore JM (2006) Archaean lode gold mineralisation in banded iron formation at the Kalahari Goldridge deposit, Kraaipan Greenstone Belt, South Africa. Miner Deposita 41: 483-503

Hagemann SG, Lüders V (2003) P-T-X conditions of hydrothermal fluids and precipitation mechanism of stibnite-gold mineralisation at the Wiluna lode-gold deposits, Western Australia; conventional and infrared microthermometric constraints. Miner Deposita 38: 936-952

Hagemann SG, Cassidy KF (2000) Archaean orogenic gold deposits. In: Hagemann SG, Brown PE (eds) Gold in 2000. Rev Econ Geol 13: 9-68

Hodgson CJ (1993) Mesothermal lode-gold deposits. In: Kirkham RV, Sinclair WD, Thorpe RI, Duke JM (eds) Mineral deposit modelling, Geol Assoc Canada 40: 635-678

Kerrich R, Fyfe WS (1981) The gold-carbonate association: source of $\mathrm{CO}_{2}$, and $\mathrm{CO}_{2}$ fixation reactions in Archaean lode deposits. Chem Geol 33: 265-294

Kerrich R, Goldfarb R, Groves D, Garwin S (2000) The geodynamics of world-class gold deposits: characteristics, spacetime distribution, and origins. In: Hagemann SG, Brown PE (eds) Gold in 2000. Rev Econ Geol 13: 501-551

Loucks RR, Mavrogenes JA (1999) Gold solubility in supercritical hydrothermal brines measured in synthetic fluid inclusions. Science 284: 2159-2163

Martelat JE, Lardeaux JM, Nicollet C, Rakotondrazafy R (2000) Strain pattern and late Precambrian deformation history in southern Madagascar. Precamb Res 102: 1-20

Mikucki EJ (1998) Hydrothermal transport and depositional processes in Archaean lode-gold systems: a review. Ore Geol Rev 13: 307-321

Mikucki EJ, Groves DI (1990) Genesis of primary gold deposits: gold transport and depositional models. In: Ho SE, Groves DI, Bennett JM (eds) Gold deposits of the Archaean Yilgarn Block, Western Australia: Nature, Genesis and Exploration Guides. Geology Department and University Extension, The University of Western Australia, Publication 20, pp 212-220 Mikucki EJ, Ridley JR (1993) The hydrothermal fluid of Archaean lode-gold deposits at different metamorphic grades: compositional constraints from ore and wall rock alteration assemblages. Miner Deposita 28: 469-481

Nawaratne SW, Dissanayake CB (2001) Gold occurrences in Madagascar, South India and Sri Lanka: Significance of a possible Pan-African event. Gondwana Res 4: 367-375

Phillips GN, Groves DI, Martyn JE (1984) An epigenetic origin for Archaean banded iron-formation-hosted gold deposits.

Econ Geol 79: 162-171

Phillips GN, Powell R (1992) Gold-only provinces and their common features. Contribution of the Economic Geology Research Unit 43:27

Pretorius AI, Van Reenen DD, Barton JM (1988) BIF-hosted gold mineralisation at the Fumani Mine, Sutherland greenstone belt, South Africa. Trans Geol Soc South Africa 91: 429-438

Rambeloson AR (1999) Gold in Madagascar. Gondwana Res 2: 423-431

Ramboz C, Pichavant M, Weisbrod A (1982) Fluid immiscibility in natural processes: use and misuse of fluid inclusion data: II. Interpretation of fluid inclusion data in terms of immiscibility. Chem Geol 37: 29-48

Ramboz C, Schnapper D, Dubessy J, (1985) The P-V-T-X- $f \mathrm{O}_{2}$ evolution of $\mathrm{H}_{2} \mathrm{O}-\mathrm{CO}_{2}-\mathrm{CH}_{4}$-bearing fluid in a wolframite vein; reconstruction from fluid inclusion studies. Geochim Cosmochim Acta 49: 205-219

Randriamanantenasoa A (1992) Etude de la série de Maevatanana, secteur Maevatanana et environs, Nord-Ouest de Madagascar. Thèse Université Antananarivo

Robert F, Kelly WC (1987) Ore-forming fluids in Archaean gold-bearing quartz veins at the Sigma Mine, Abitibi greenstone belt, Quebec, Canada. Econ Geol 82: 1464-1482 
Roedder E (1984) Fluid inclusions. Rev Mineral 12, Mineral Soc Am, 644 pp

Seward TM (1973) Thio complexes of gold and the transport of gold in hydrothermal ore solutions. Geochim Cosmochim Acta 37: 379-399

Seward TM (1989) The hydrothermal chemistry of gold and its implications for ore formation; boiling and conductive cooling as examples. In: Keays RR, Ramsay WRH, Groves DI (eds) The geology of gold deposits; the perspective in 1988 Econ Geol Monographs 6: 398-404

Shepherd TJ, Ranking AH, Alderthon DHM (1985) A practical guide to fluid inclusion studies. Blackie \& Son Ltd., Glasgow \& London, $239 \mathrm{pp}$

Sibson RH, Robert F, Poulsen KH (1988) High angle reverse faults, fluid-pressure cycling, and mesothermal gold-quartz deposits. Geology 16: 551-555

Tagirov BR, Salvi S, Schott J, Baranova NN (2005) Experimental study of gold-hydrosulphide complexing in aqueous solutions at $350-500^{\circ} \mathrm{C}, 500$ and 1000 bars using mineral buffers. Geochim Cosmochim Acta 69: 2119-2132

Tucker RD, Ashwal LD, Handke MJ, Hamilton MA, Le Grange M, Rambeloson R (1999) U-Pb geochronology and isotope geochemistry of the Archaean and Proterozoic rocks of North-Central Madagascar. J Geol 107: 125-153

Vielreicher RM, Groves DI, Ridley JR, McNaughton NJ (1994) A replacement origin for the BIF-hosted gold deposit at Mt. Morgans, Yilgarn Block, W.A. Ore Geol Rev 9: 325-347

Walsh JF, Kesler SE, Duff D, Cloke PL (1988) Fluid inclusion geochemistry of high-grade vein-hosted gold ore at the Pamour Mine, Porcupine Camp, Ontario. Econ Geol 81: 681-703

Williams-Jones AE, Migdisov AA, Archibald SM, Xiao Z (2002) Vapor-transport of ore metals. In: Hellman R, Wood SA (eds) Water-Rock Interaction, Ore Deposits, and Environmental Geochemistry: a Tribute to David A. Crerar, Geochem Soc Spec Publ pp 279-305

Williams-Jones AE, Migdisov AA, Archibald SM (2003) Vapor transport of ore metals in hydrothermal systems. Geol Soc Am Abstracts with Programs, 35: 356

Wyman D, and Kerrich R (1988) Alkaline magmatism, major structures and gold deposits: Implications for greenstone belt gold metallogeny. Econ Geol 83: 454-461

Zhang YG, Frantz JD (1987) Determination of the homogenization temperatures and densities of supercritical fluids in the system NaCl-KCl-CaCl ${ }_{2}-\mathrm{H}_{2} \mathrm{O}$ using synthetic fluid inclusions. Chem Geol 64: 335-350

Zotov AV, Baranova NN (1989) Thermodynamic properties of the aurochloride solute complex $\mathrm{AuCl}_{2}{ }^{-}$at temperatures of $350-500^{\circ} \mathrm{C}$ and pressures of 500-1500 bars. Sci Geol Bull 42:335-342

\section{Figure Captions}

Fig. 1 Geological map showing the principal tectonic units of Madagascar (modified after Collins et al. 2003)

Fig. 2 Geological map of the Maevatanana region between the Ikopa and Betsiboka Rivers, showing the distribution of granitoids, greenstones, probable faults and the Maevatanana gold district (modified after Bésairie 1963, 1973).

Fig. 3 Images of BIF layers and associated mineralisation. a) A hand sample showing a sulphide (sulph)-rich quartz band cutting at a shallow angle dark magnetite (Mag)-rich bands (MAE-I-3L). b) Slab showing a quartz vein cross-cutting BIF layering (MAE-I-1C). c) Photomicrographs under transmitted cross-polarized light (XPL) and reflected plain-polarized light (RL) of BIF layering cross-cut by a quartz vein (MAE-A-3a). The insets show details of altered BIF immediately adjacent to the quartz vein (localized in the large image by the white box); they illustrate the partial replacement of magnetite (Mag) by pyrite (Py) and chalcopyrite (Ccp), as well as incomplete pseudomorphism of primary magnetite by hematite (Hem).

Fig. 4 Photomicrograph of gold grains within a quartz vein (RL) (MAE-8-2c). The gold grains (Au) occur as inclusions within quartz (Qtz), and in a small fissure associated with galena (Gn). The largest gold grain measures $100 \mu \mathrm{m}$.

Fig. 5 Photomicrographs showing: a) Isolated primary Type-II and Type IIIb inclusions; b) a trail of secondary fluid inclusion cross-cutting quartz grain boundaries; c) coexisting Type-II inclusions showing variable $\mathrm{CO}_{2} / \mathrm{H}_{2} \mathrm{O}$ ratios; d) trails of pseudosecondary fluid inclusions in quartz grains. All images are in plain-polarized transmitted light (PPL). Samples MAE-A-3c (a and c), MAE-8 (b), MAE-28b (d).

Fig. 6 Histograms showing a) melting temperature of $\mathrm{CO}_{2}$ ice $\left(\mathrm{T}_{\mathrm{m}} \mathrm{CO}_{2}\right)$ and $\mathrm{b}$ ) homogenisation temperature of $\mathrm{CO}_{2}\left(\mathrm{~T}_{\mathrm{h}} \mathrm{CO}_{2}\right)$ for Type-I and Type-II fluid inclusions.

Fig. 7 Salinity (wt\% eq. $\mathrm{NaCl}$ ) of aqueous and aqueous-carbonic fluid inclusions.

Fig. 8 Histogram of total homogenisation temperature ( $\mathrm{T}_{\mathrm{h}}$ tot) for Type-II and Type-III inclusions.

Fig. 9 Representative Raman spectra of Type-I and of the carbonic phase in Type-II inclusions. The spectra confirm that the carbonic phase in both inclusion types consists of $\mathrm{CO}_{2}$ and show the occasional presence of traces of $\mathrm{CH}_{4}(<1 \mathrm{~mol} \%)$ and $\mathrm{H}_{2} \mathrm{~S}(<0.1 \mathrm{~mol} \%)$.

Fig. 10 Representative isochores for $\mathrm{H}_{2} \mathrm{O}-\mathrm{NaCl}-\mathrm{CO}_{2} \pm \mathrm{CH}_{4} \pm \mathrm{H}_{2} \mathrm{~S}$ fluid inclusions trapped in quartz-sulphide veins. Isochores A-B and C-D cover the density range of Type-II and Type-I inclusions, respectively. The average and $1 \sigma$ standard deviation of the homogenization temperature of Type-II inclusions is shown by the vertical lines.

Fig. 11 Calculated solubility of gold at $250^{\circ} \mathrm{C}$ and $1 \mathrm{~kb}$, computed as a function of $f \mathrm{H}_{2(\mathrm{~g})}$ and $a \mathrm{H}_{2} \mathrm{~S}_{(\mathrm{aq})}$ for a $1 \mathrm{~m}$ $\mathrm{KCl}$ aqueous solution in equilibrium with the quartz-muscovite-K-feldspar $\mathrm{pH}$ buffer. The dashed lines represent 
the solubility of gold $\left(\Sigma \mathrm{Au}=\mathrm{mAuCl}_{2}{ }^{-}+\mathrm{mAuHS}^{0}+\mathrm{mAuHS}\left(\mathrm{H}_{2} \mathrm{~S}\right)_{3}{ }^{0}+\mathrm{mAu}(\mathrm{HS})_{2}{ }^{-}\right.$; cf. Benning and Seward 1996; Gibert et al. 1998; Loucks and Mavrogenes 1999; Tagirov et al. 2005). The solid lines separate the stability fields of pyrite, pyrrhotite, magnetite, and hematite. The arrow is a schematic illustration of a possible evolution path of a gold undersaturated hydrothermal fluid reacting with a quartz-magnetite bearing rock. 
Table 1 - Representative electron microprobe analyses of sulphides and magnetite.

\begin{tabular}{|c|c|c|c|c|c|c|c|c|c|c|}
\hline & \multicolumn{7}{|c|}{ Sulphides } & \multicolumn{3}{|c|}{ Oxydes } \\
\hline & Pyrite & & & & Chalcopyrite & & Galena & Magnetite & & \\
\hline$S$ & 53.03 & 52.07 & 52.38 & 53.59 & 35.12 & 35.18 & 13.50 & $\mathrm{SiO} 2$ & 0.06 & 0.02 \\
\hline $\mathrm{Fe}$ & 47.07 & 47.04 & 47.11 & 47.10 & 30.35 & 30.36 & 0.00 & $\mathrm{TiO} 2$ & 0.00 & 0.00 \\
\hline Co & 0.26 & 0.27 & 0.11 & 0.00 & 0.04 & 0.02 & 0.00 & $\mathrm{Fe} 2 \mathrm{O} 3(\mathrm{c})$ & 69.04 & 69.18 \\
\hline $\mathrm{Cu}$ & 0.05 & 0.04 & 0.00 & 0.00 & 34.27 & 34.89 & 0.00 & $\mathrm{FeO}$ & 30.96 & 31.03 \\
\hline As & 0.19 & 0.14 & 0.17 & 0.15 & 0.04 & 0.00 & 0.00 & $\mathrm{MnO}$ & 0.18 & 0.00 \\
\hline $\mathrm{Ag}$ & 0.10 & 0.00 & 0.01 & 0.05 & 0.00 & 0.02 & 0.00 & $\mathrm{ZnO}$ & 0.00 & 0.10 \\
\hline $\mathrm{Au}$ & 0.00 & 0.00 & 0.01 & 0.15 & 0.00 & 0.00 & 0.00 & $\mathrm{NiO}$ & 0.07 & 0.09 \\
\hline $\mathrm{Pb}$ & 0.00 & 0.00 & 0.00 & 0.00 & 0.00 & 0.00 & 86.14 & & & \\
\hline Total & 100.70 & 99.56 & 99.79 & 101.04 & 99.82 & 100.48 & 99.64 & Total & 100.39 & 100.46 \\
\hline
\end{tabular}

all values in wt\% 
Table 2 - Microprobe analyses of gold. Figures in parentheses are $(1 \sigma)$ standard deviations; $n=$ number of averaged analyses; $n . d .=$ not detected.

\begin{tabular}{cc}
\hline \hline $\mathrm{n}=12$ & $\mathrm{wt} \%$ \\
\hline $\mathrm{Au}$ & $92.36(0.88)$ \\
$\mathrm{Ag}$ & $7.13(0.12)$ \\
$\mathrm{Cu}$ & $0.04(0.01)$ \\
$\mathrm{S}$ & $0.01(0.01)$ \\
$\mathrm{Fe}$ & $0.02(0.02)$ \\
$\mathrm{Co}$ & $0.01(0.00)$ \\
$\mathrm{As}$ & $0.02(0.02)$ \\
$\mathrm{Pb}$ & $\mathrm{n} . \mathrm{d}$ \\
Total & $99.58(0.92)$ \\
& \\
Fineness & $938(9)$ \\
\hline
\end{tabular}


Table 3 - Fluid inclusion types, origin and major chemistry.

\begin{tabular}{ccc} 
Inclusion type & Origin & $\begin{array}{l}\text { Major component } \\
\mathrm{CO}_{2}>>\mathrm{H}_{2} \mathrm{O}-\mathrm{NaCl} \\
\text { Type I }\end{array}$ \\
\hline Type II & P, PS & $\begin{array}{l} \pm \mathrm{CH}_{4} \pm \mathrm{H}_{2} \mathrm{~S} \pm \mathrm{N}_{2} \\
\mathrm{CO}_{2}-\mathrm{H}_{2} \mathrm{O}-\mathrm{NaCl} \\
\pm \mathrm{CH}_{4} \pm \mathrm{H}_{2} \mathrm{~S} \pm \mathrm{N}_{2}\end{array}$ \\
& P,PS, S & \\
Type III & P, PS & $\mathrm{H}_{2} \mathrm{O}-\mathrm{NaCl} \pm \mathrm{KCl}$
\end{tabular}


Table 4 - Quantitative data for fluid inclusions from gold-bearing sulphide-rich quartz veins. Calculated from microthermometric and Raman data and the MacFlinCor software of Brown and Hagemann (1995)

\begin{tabular}{cccccccc}
\hline \hline $\begin{array}{c}\text { Inclusion } \\
\text { type }\end{array}$ & Origin & Eq. NaCl & $\mathrm{X} \mathrm{CO}_{2}{ }^{* *}$ & $\mathrm{X} \mathrm{CH}_{4} \pm \mathrm{H}_{2} \mathrm{~S}^{* *}$ & $\mathrm{X} \mathrm{NaCl}^{* *}$ & dBulk $^{\#}$ & $\begin{array}{c}\text { Bulk molar } \\
\text { volume }\end{array}$ \\
\hline Type I & P, PS & $\approx 0$ & 0,83 & $\leq 0.17$ & $\leq 0.01$ & $0.65-0.88$ & $45.08-61.03$ \\
Type II & P, PS, S & $\begin{array}{c}0.4 \text { to } 7.4 \\
(3.6)\end{array}$ & $0.10-0.52$ & $0.48-0.89$ & $0.002-0.01$ & $0.73-0.94$ & $22.37-43.50$ \\
Type III & P, PS & $\begin{array}{c}0.6 \text { to } 7.2 \\
(3.9)\end{array}$ & - & - & $0.002-0.22$ & $1.04 \pm 0.2$ \\
& & & & & & \\
\hline
\end{tabular}

* in wt\%. Average compositions are shown in brackets.

** expressed in mol

\# expressed in $\mathrm{g} \mathrm{cm}^{-3}$

\#\# expressed in $\mathrm{m}^{3} \mathrm{~mol}^{-1}$ 


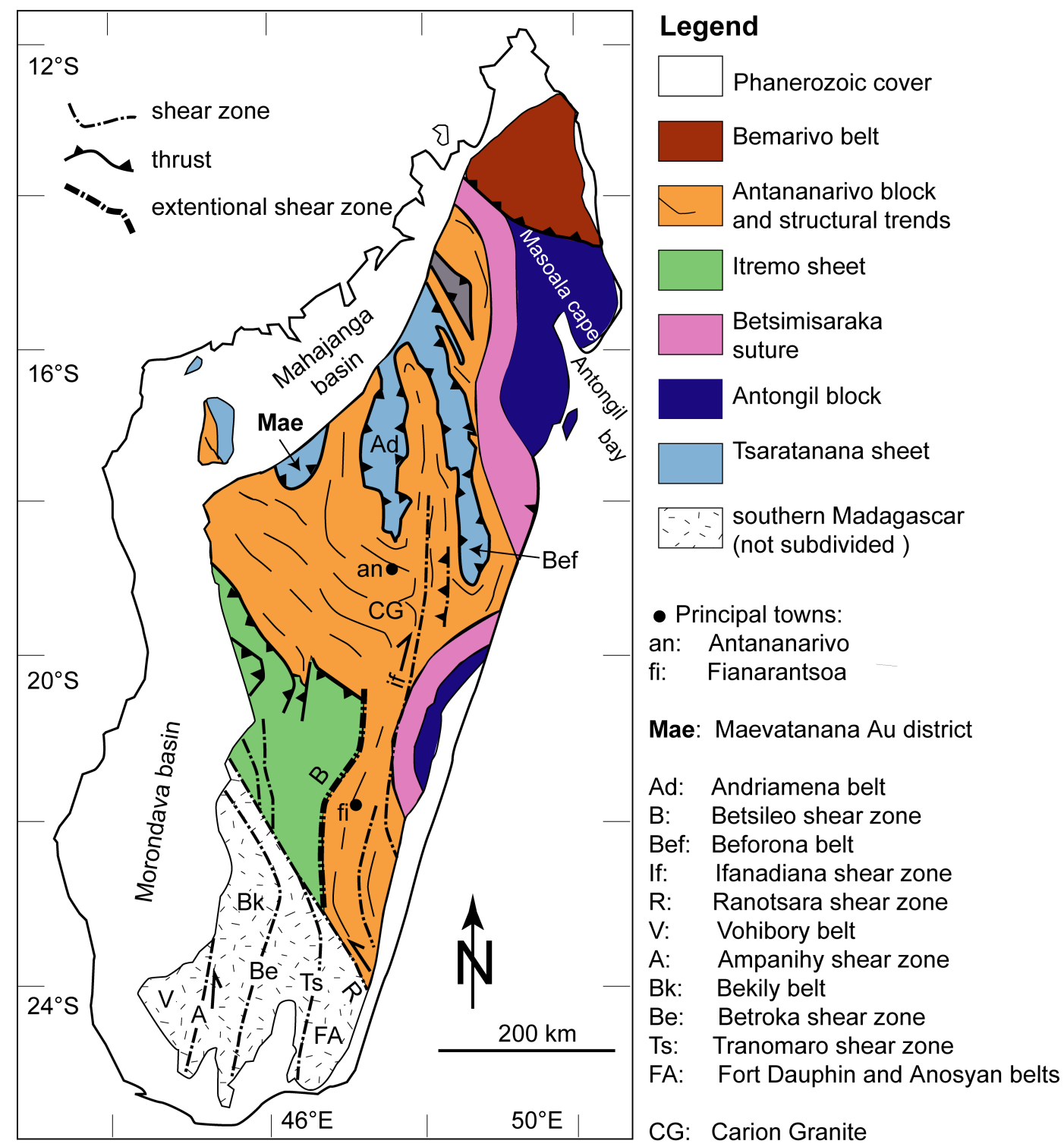

Fig. 1 


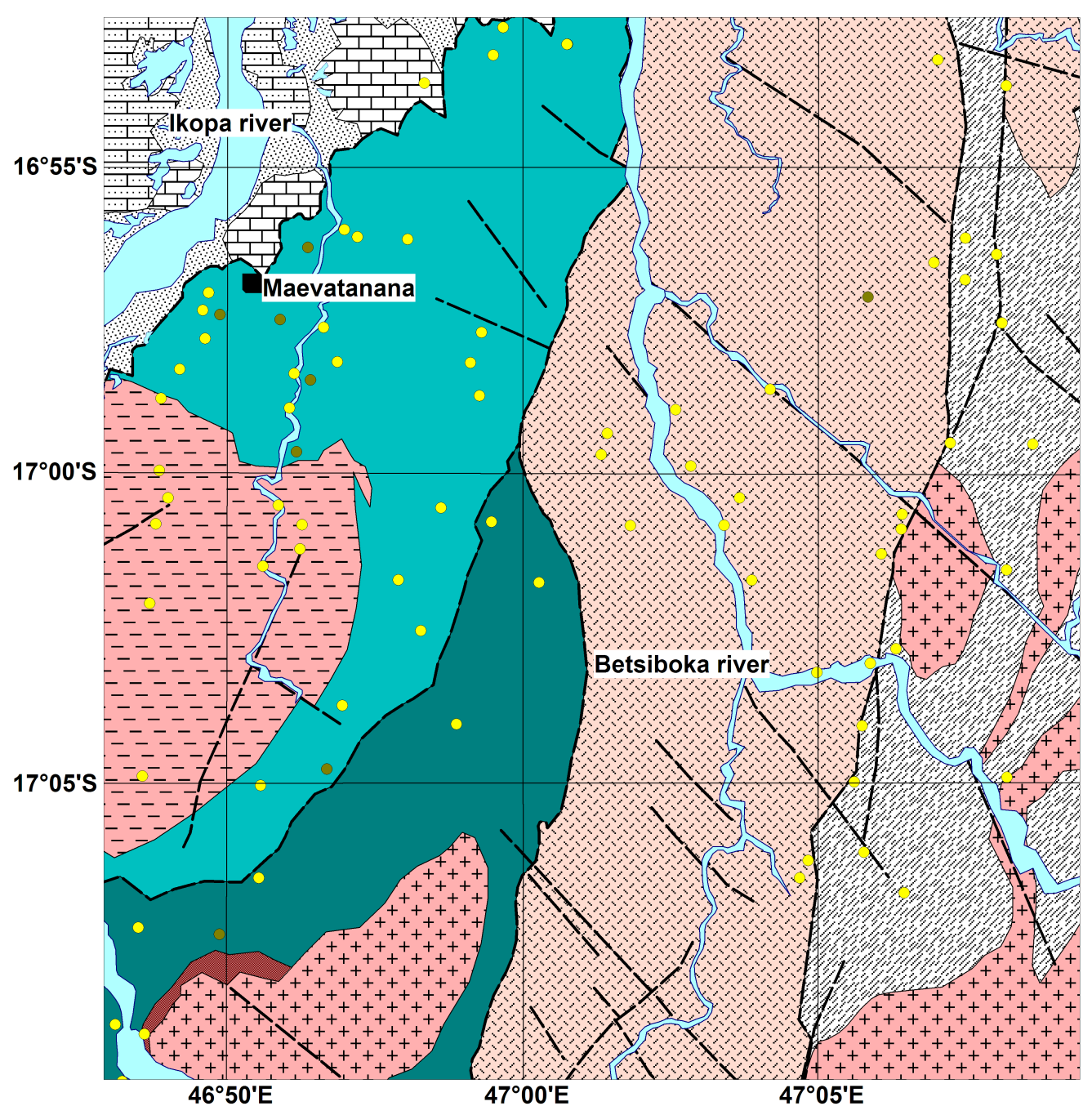

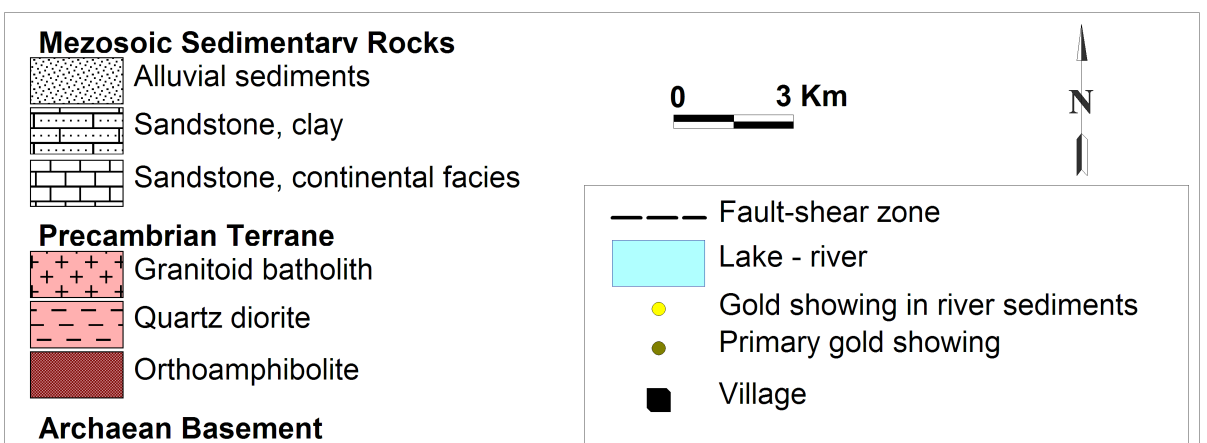

\begin{tabular}{l} 
Upper crustal level: gneiss, magnetite-rich quartzite, amphibolite, soapstone \\
Supracrustal sequence of gneiss, amphibolite, magnetite-rich quartzite \\
\hline Lower crustal level: migmatite \\
Lneissic basement
\end{tabular}

Fig. 2 


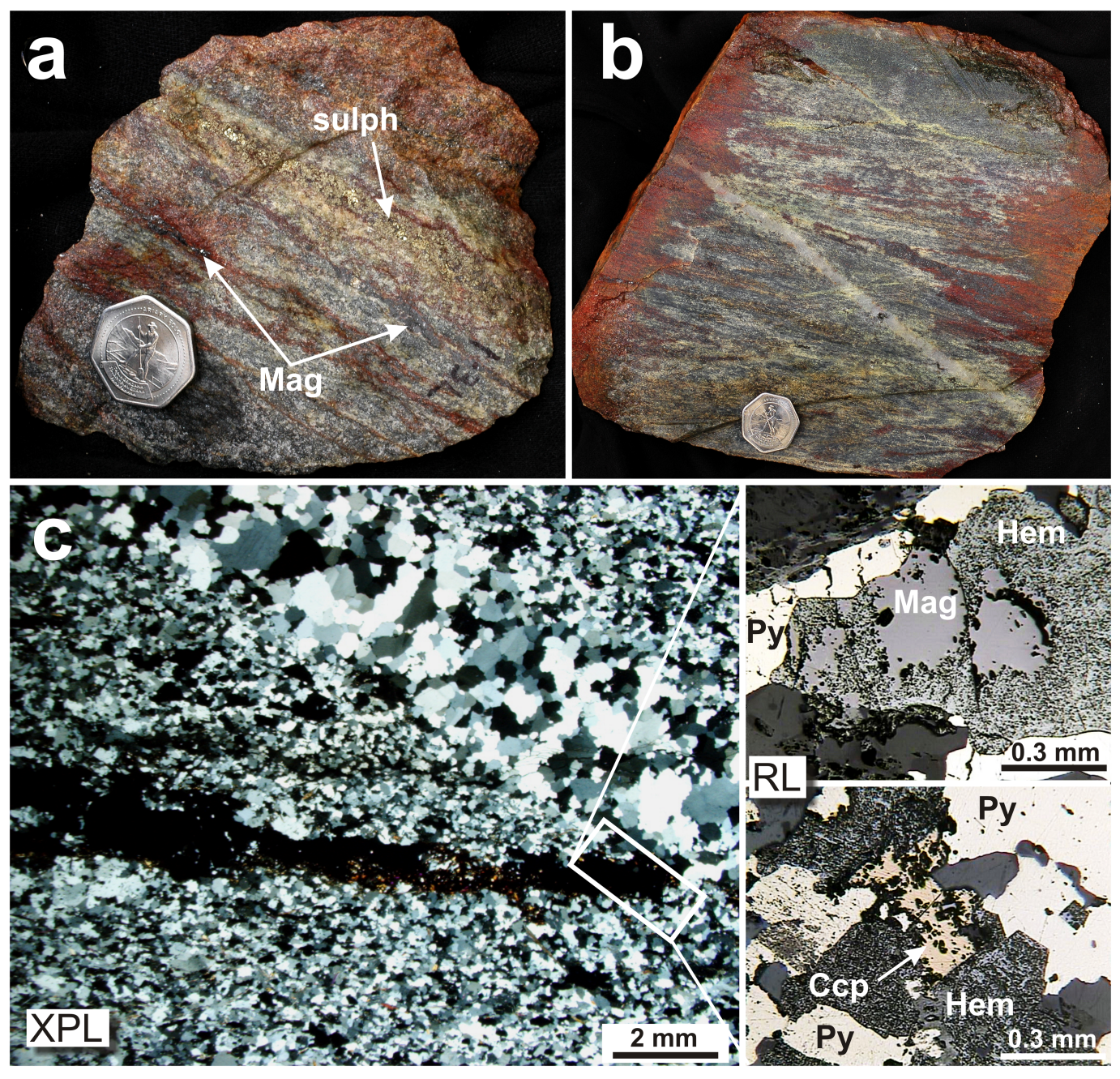

Fig. 3 


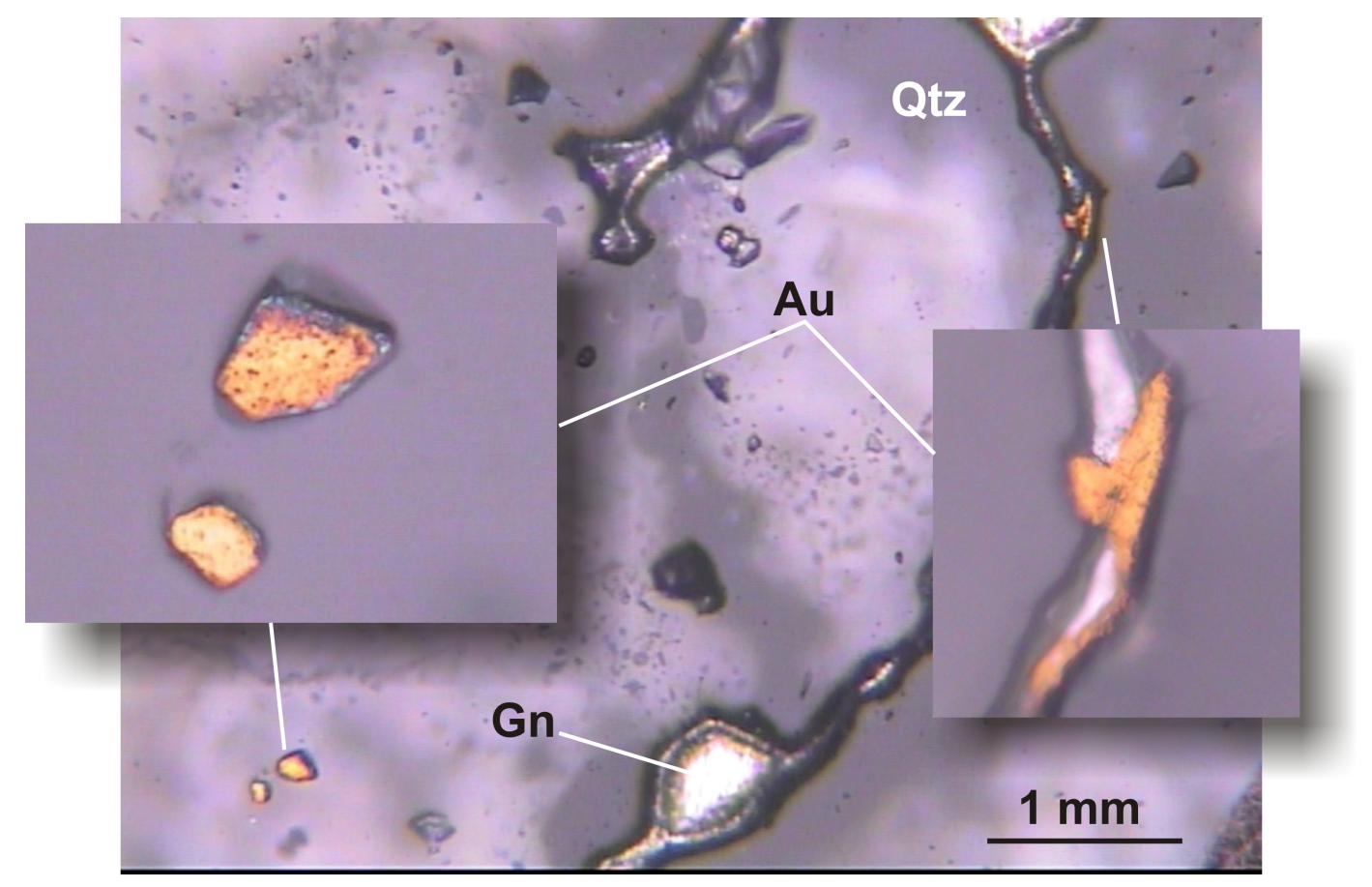

Fig. 4 


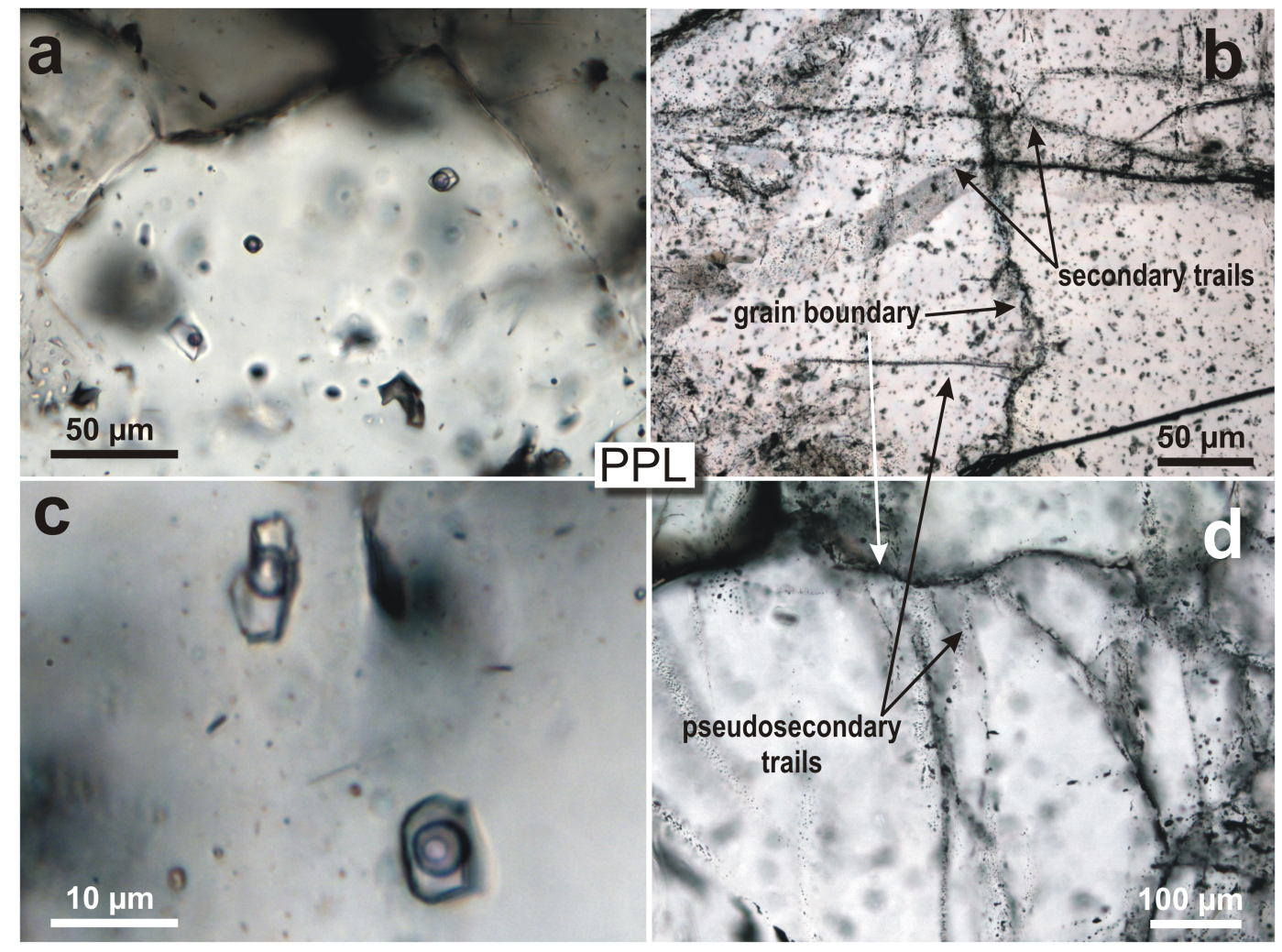

Fig. 5 

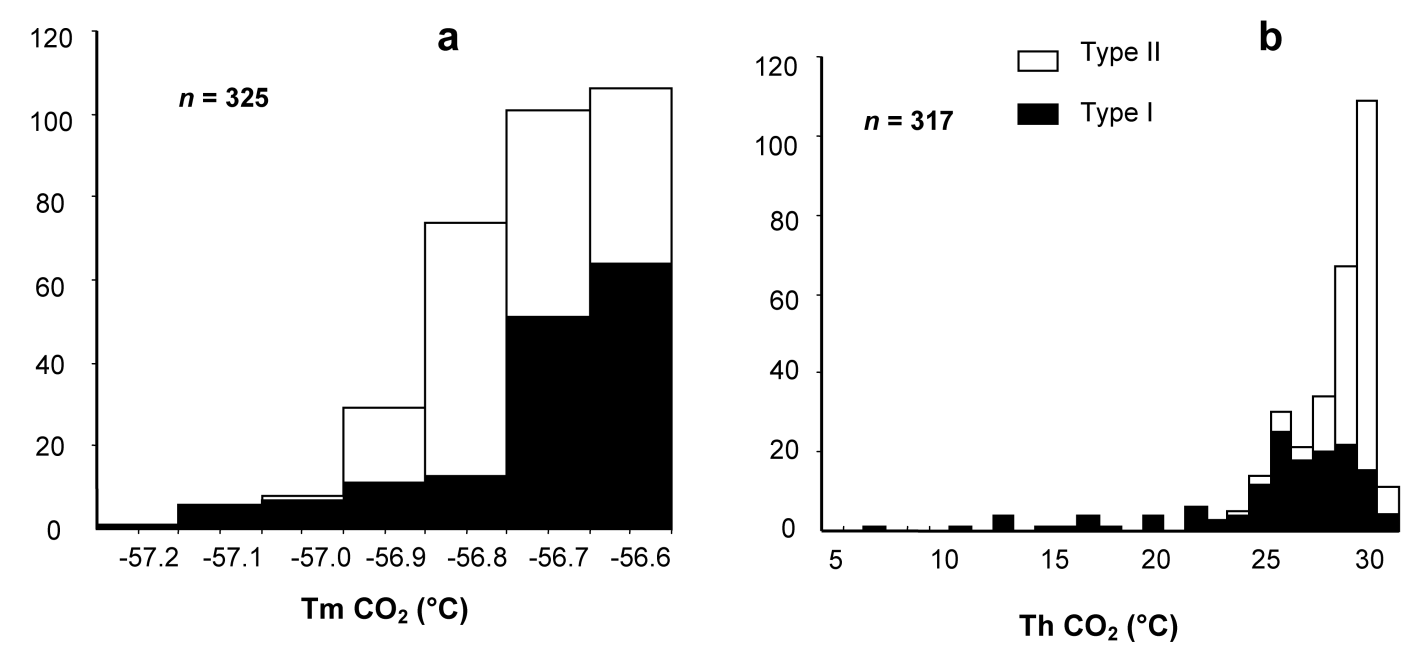

Fig. 6 


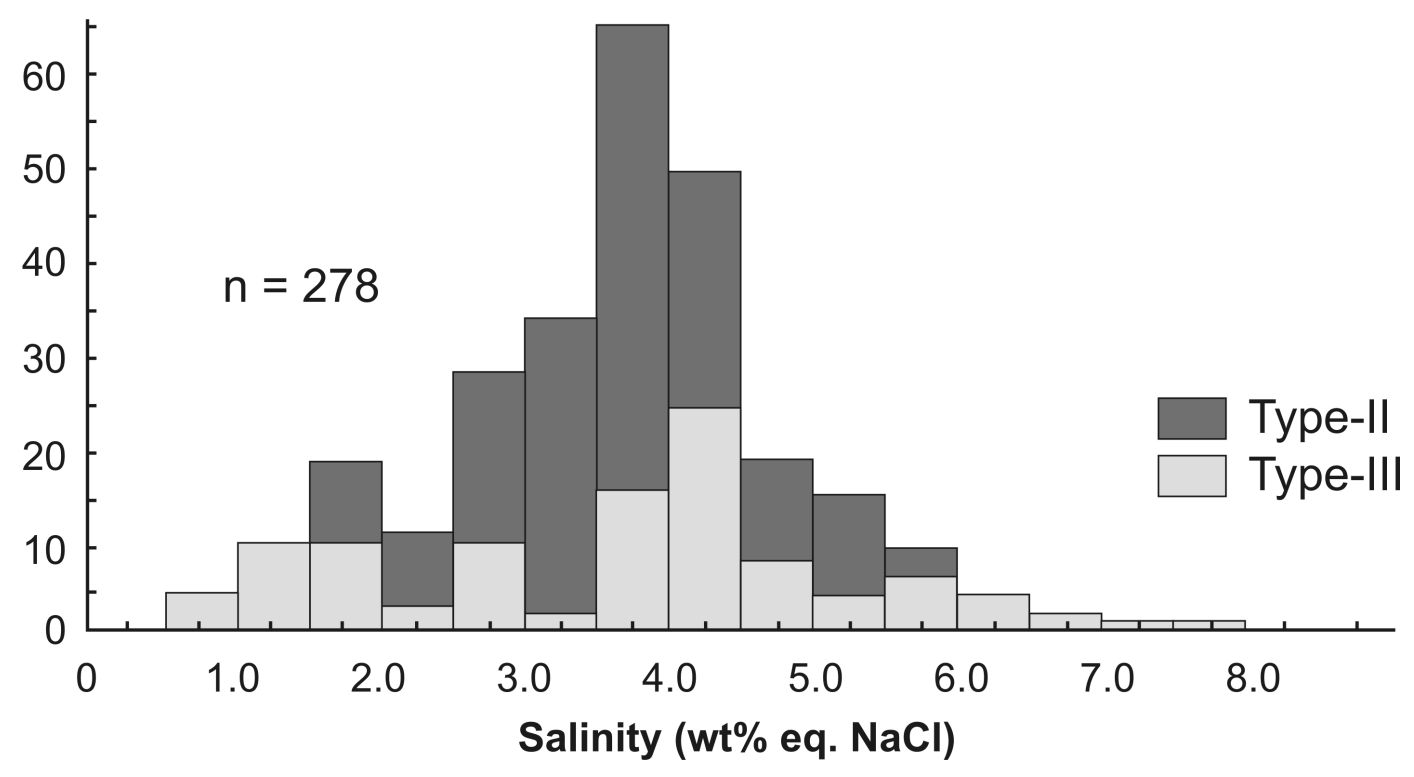

Fig. 7 


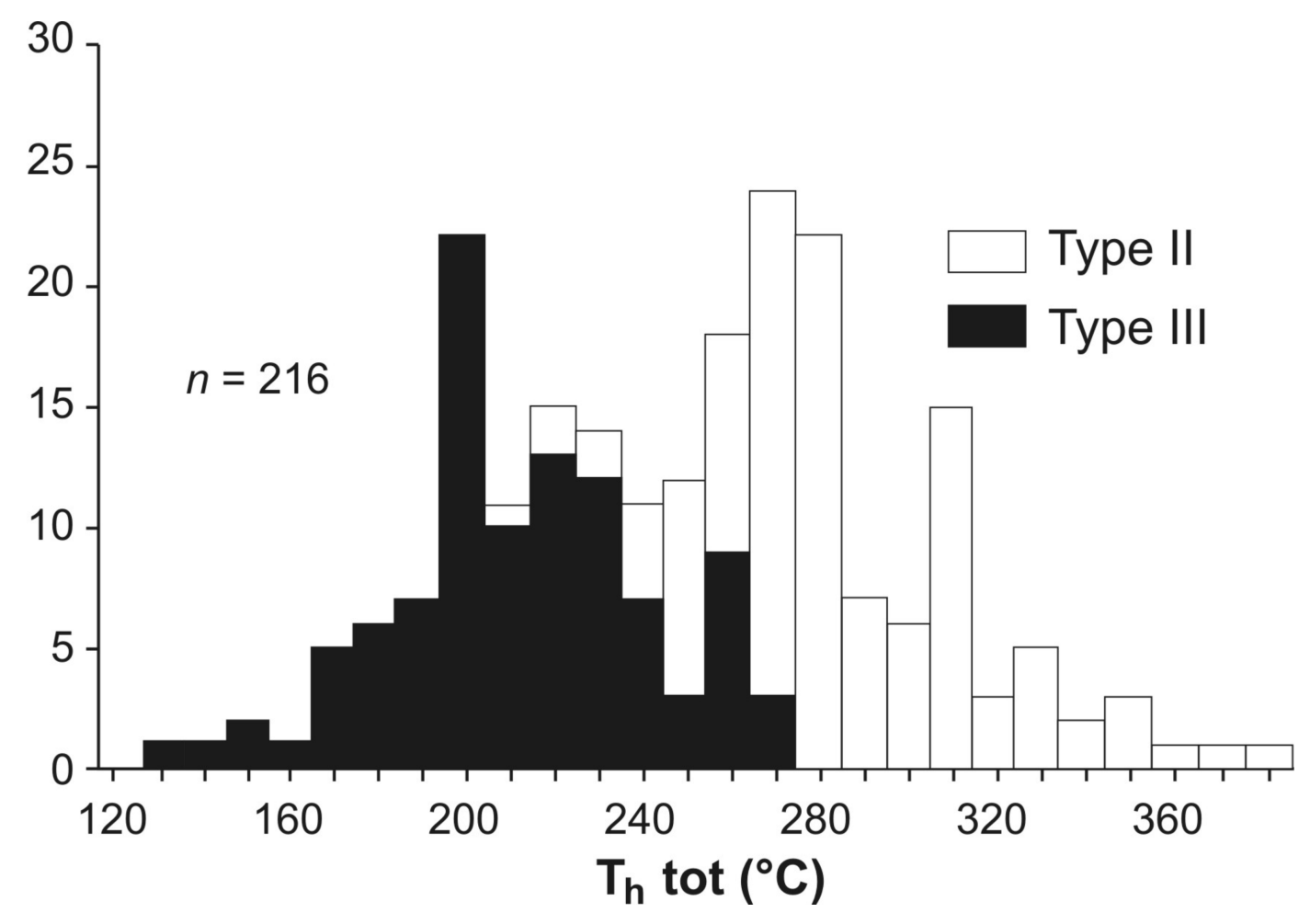

Fig. 8 

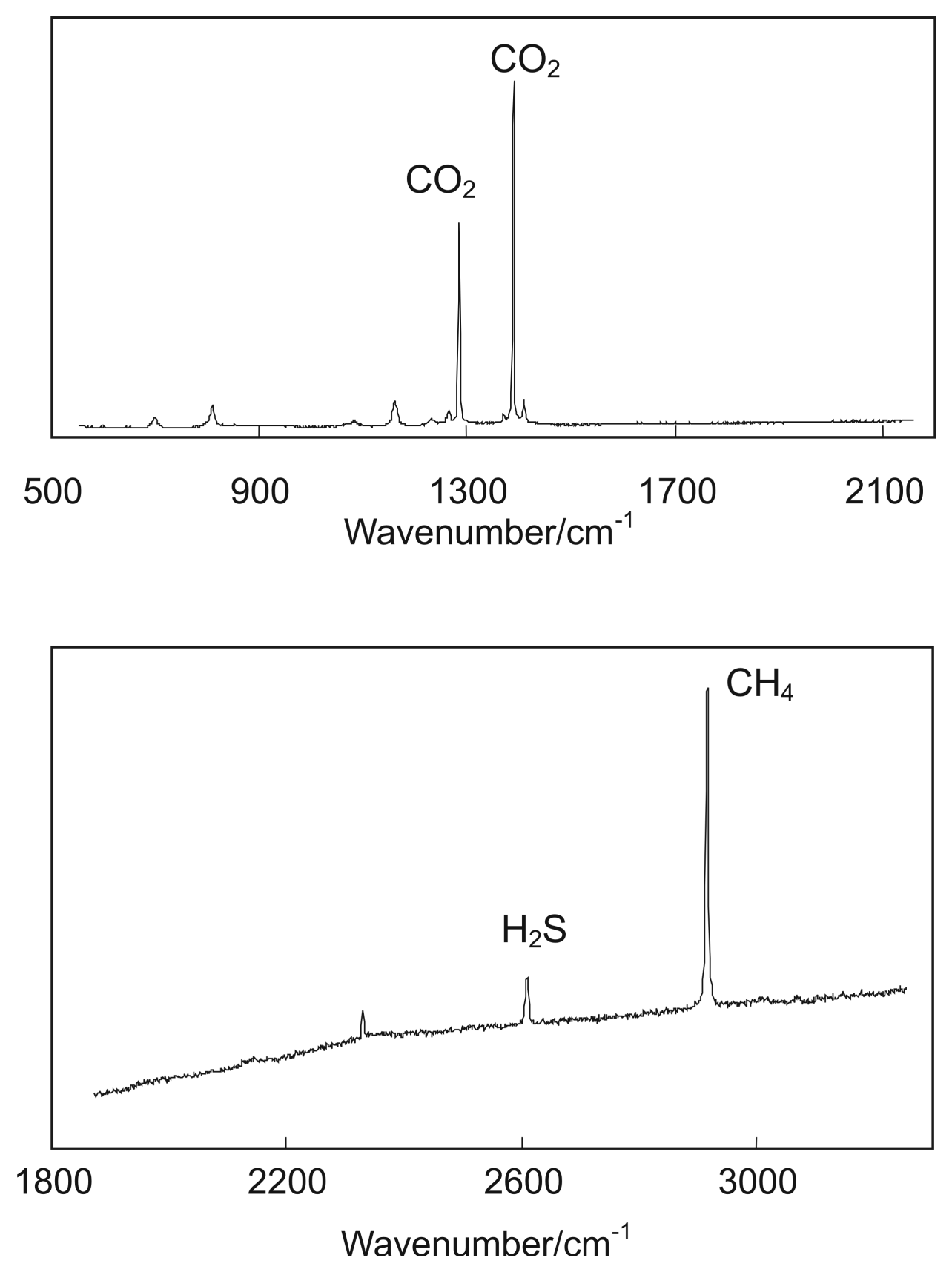

Fig. 9 


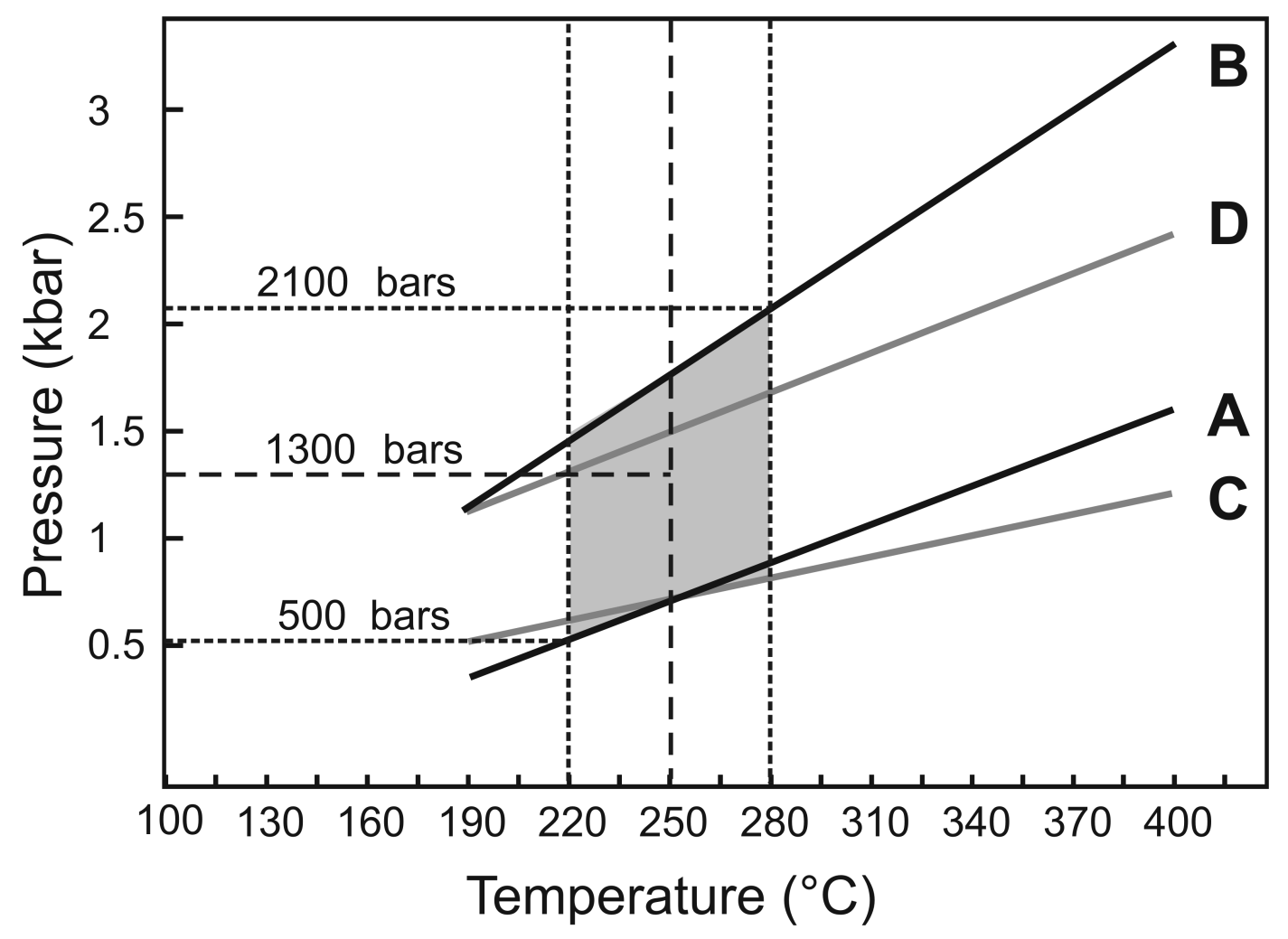

Fig. 10 


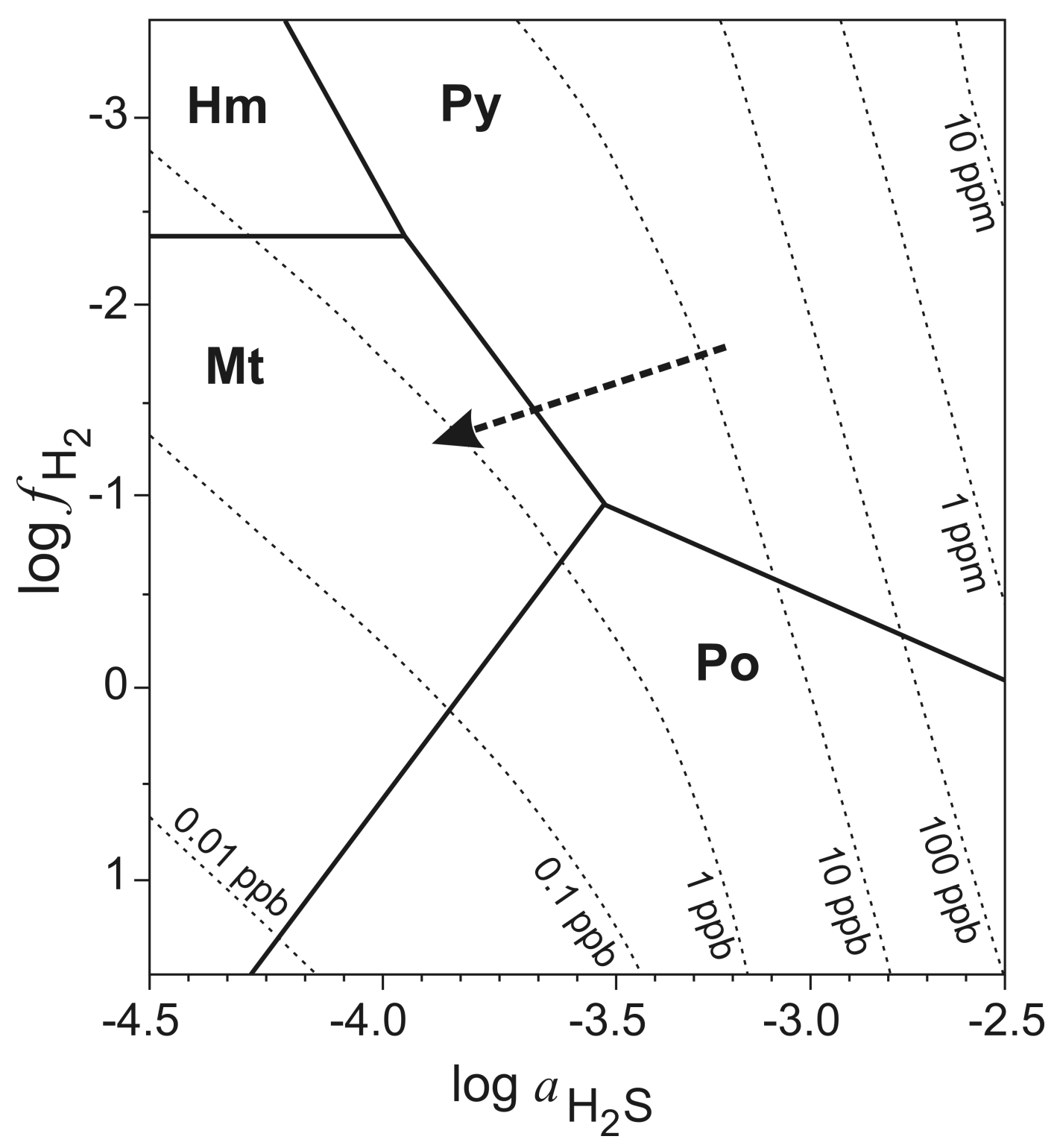

Fig. 11 